\title{
Effect of the Processing Parameters on the Crystalline Structure of Lanthanide Orthotantalates
}

\author{
Kisla P. F. Siqueira, Anderson Dias* \\ Departamento de Química, Universidade Federal de Ouro Preto - UFOP, Campus Morro do Cruzeiro, \\ ICEB II, Sala 67, CEP 35400-000, Ouro Preto, MG, Brazil
}

Received: June 20, 2013; Revised: October 8, 2013

\begin{abstract}
The influence of the synthesis parameters on the crystalline structures of orthotantalate ceramics has been investigated. Powder materials were prepared by the solid-state reaction route. X-ray diffraction and Raman scattering measurements were employed to investigate the crystal structure of the produced materials. In this work, we analyzed three different examples in which the temperature and time were decisive on the final crystal structure of $\mathrm{LnTaO}_{4}$ compounds besides the lanthanide ionic size. Firstly, the thermal evolution for $\mathrm{NdTaO}_{4}$ samples showed that mixed crystal phases are formed up to $1100^{\circ} \mathrm{C}$, while well-crystallized $\mathrm{M}-\mathrm{NdTaO}_{4}$ (I//a) materials are obtained in temperatures higher than $1200^{\circ} \mathrm{C}$. Also, the influence of the synthesis time was investigated for the $\mathrm{LaTaO}_{4}$ ceramics: it was necessary $14 \mathrm{~h}$ to obtain samples in the $\mathrm{P}_{1} / \mathrm{c}$ structure. Finally, two polymorphs could be obtained for the $\mathrm{DyTaO}_{4}$ ceramics: P2/a and I2/a space groups were obtained at $1300{ }^{\circ} \mathrm{C}$ and $1500{ }^{\circ} \mathrm{C}$, respectively. This study indicated that the temperature, time and lanthanide size are directly correlated with the crystalline arrangement of the orthotantalate materials.
\end{abstract}

Keywords: solid-state processing, lanthanide orthotantalates, crystal structure, Raman spectroscopy

\section{Introduction}

Ceramic materials have always been, and will continue to be, an inseparable part of human life. They are essential constituents in all modern technologies and devices including computers, displays, solid-state phosphors, photocatalysts, batteries, cars, spacecrafts among others ${ }^{1,2}$. Due to their unique combination of properties, such as hardness, high chemical and electrochemical stabilities, photo-electronic activity, ion-conductivity, luminescence and magnetic behavior, ceramic materials have become irreplaceable in a broad variety of applications $\mathrm{s}^{3-7}$. The focus of this work is the lanthanide orthotantalates $\left(\mathrm{LnTaO}_{4}\right)$, which belong to the class of electroceramics and have been extensively studied in recent years because of their huge range of environmental- and energy-related applications ${ }^{8,9}$.

A series of polymorphic modifications, which belong to the structures usually found in $\mathrm{BaMnF}_{4}, \mathrm{M}$ - and $\mathrm{M}$ '-fergusonite and scheelite, are known for $\mathrm{LnTaO}_{4}$ compounds ${ }^{10-13}$. The samples with larger ionic radius of $\operatorname{Ln}(\mathrm{Ln}=\mathrm{La}-\mathrm{Pr})$ exhibit two perovskite-like layered polymorphic modifications with monoclinic $\mathrm{LaTaO}_{4}{ }^{-}$ type and $\mathrm{BaMnF}_{4}$-type structures. The other lanthanides $(\mathrm{Ln}=\mathrm{Nd}-\mathrm{Lu})$ crystallize in the monoclinic form, besides their ability to possess two fergusonite-type structures. The first one belongs to the space group I2/a, known as M-type structure, while the second one belongs to the space group P2/a, called M'-type structure ${ }^{10,13,14}$. Implementation of either of these structure types for $\mathrm{LnTaO}_{4}$ depends not only on the Ln atomic radius, but also on the synthesis conditions

*e-mail: anderson_dias@iceb.ufop.br during the different sample preparation procedures. This leads to numerous disagreements in the data about how the structural stability ranges as well as in the regions where the polymorphic modifications occur, including their crystal structure and other properties for $\mathrm{LnTaO}_{4}{ }^{[11-15]}$.

Lanthanide orthotantalates can be prepared by different techniques. However, all of the existing techniques for the preparation of tantalates have two serious drawbacks: they require high temperatures and considerable time because of the low reactivity of the oxides involved and slow diffusion rates ${ }^{16}$. In general, the incompatibility between acid-soluble rare-earth oxides and based-soluble tantalum oxides render aqueous solution preparations more difficult ${ }^{1}$. Thereby, the most commonly employed methodology for the production of orthotantalates is the solid-state reaction, which requires repeated milling procedures besides high reaction temperatures. Moreover, due to the intermediate compounds that are involved in the synthesis mechanism, the crystalline homogeneity of powder materials is difficult to achieve.

The synthesis parameters have strong influence on the crystal structure, purity, crystalline degree of order, particle size and morphology of the orthotantalate compounds ${ }^{17}$. Since all these aspects determine the properties and performance of these materials, the study of their processing conditions becomes very important. At our knowledge, systematic studies concerning the processing of orthotantalates were not yet reported in the literature. We believe that the lack of studies about the methodology for 
their production is related with the difficult in synthesizing $\mathrm{LnTaO}_{4}$ samples. This fact motivated our work, whose the goal is discuss the influence of the synthesis parameters such as temperature, time and lanthanide size on the crystal structure resulting of orthotantalates ceramics processed by solid-state reaction.

\section{Experimental Procedure}

Orthotantalate ceramics were synthesized by using $\mathrm{Ln}_{2} \mathrm{O}_{3}(\mathrm{RE}=\mathrm{La}, \mathrm{Nd}$ and $\mathrm{Dy} ;>99.9 \%$ Sigma-Aldrich $)$ and $\mathrm{Ta}_{2} \mathrm{O}_{5}(>99.9 \%$ Sigma-Aldrich) as starting materials through the solid-state reaction. Stoichiometric amounts were weighed and mixed with a mortar and pestle. The mixed powders were calcined in different rates of time and temperature aiming to obtain crystalline structures. Firstly, the fixed time of $6 \mathrm{~h}$ were employed to investigate the structural evolution as a function of temperature. After adjusting this parameter, the syntheses occur under different processing times up to $14 \mathrm{~h}$.

All samples were characterized by X-ray diffraction (XRD) using a Shimadzu D-6000 diffractometer with graphite monochromator and a nickel filter in the range of $10-60^{\circ} 2 \theta\left(15 \mathrm{~s} / \mathrm{step}\right.$ of $\left.0.02^{\circ} 2 \theta\right)$, operating with FeK $\alpha$ radiation $(\lambda=0.1936 \mathrm{~nm}), 40 \mathrm{kV}$ and $20 \mathrm{~mA}$. The results were automatically converted to $\mathrm{CuK} \alpha$ radiation $(\lambda=0.1540 \mathrm{~nm})$ for data treatment and manipulation. Raman spectra of the synthesized samples were collected in backscattering configuration by using an Horiba/Jobin-

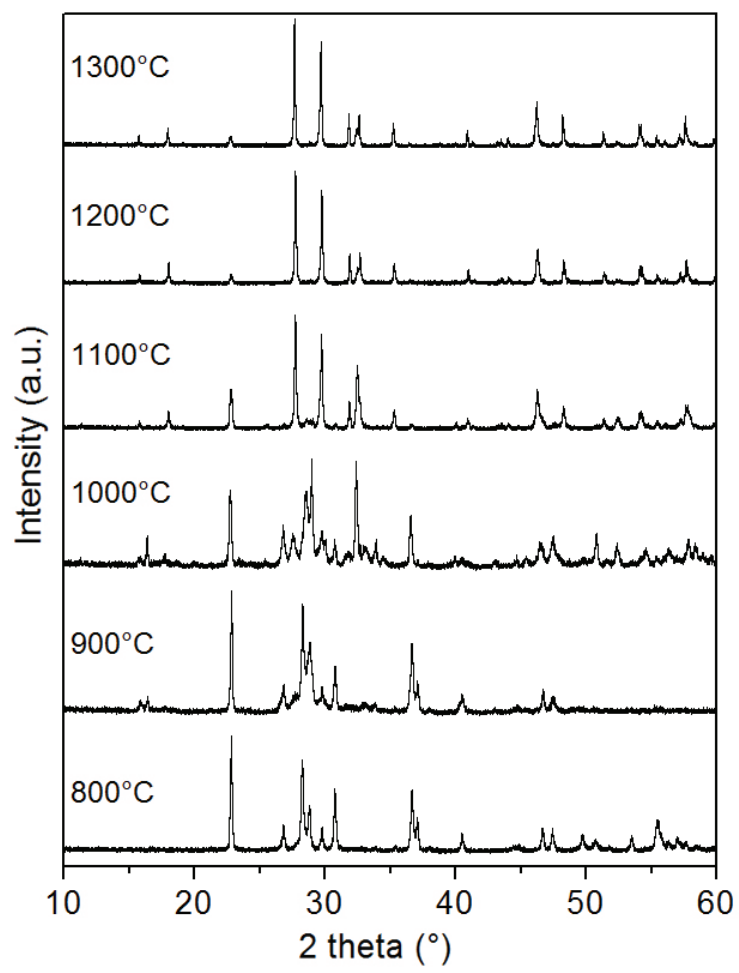

(a)
Yvon LABRAM-HR spectrometer with the $632.8 \mathrm{~nm}$ line of a helium-neon laser (effective power of $6 \mathrm{~mW}$ at the sample's surface) as excitation source. This equipment has diffraction gratings of 600 and 1800 grooves $/ \mathrm{mm}$, Peltiercooled CCD detector and confocal Olympus microscope (100× objective). The experimental resolution was typically $1 \mathrm{~cm}^{-1}$ for 10 accumulations of $30 \mathrm{~s}$. Appropriate interference filter for rejecting laser plasma lines, edge filter for stray light rejection were used. All resulting spectra were corrected by Bose-Einstein thermal factor ${ }^{18}$.

\section{Results and Discussion}

The thermal evolution study for the $\mathrm{NdTaO}_{4}$ sample was carried out to investigate the influence of the temperature on its crystallization behavior. Figure 1 presents XRD patterns obtained for samples calcined in air at temperatures ranging from 800 to $1300^{\circ} \mathrm{C}$, for $6 \mathrm{~h}$. Samples synthesized at temperatures below $1000{ }^{\circ} \mathrm{C}$ exhibited mixed crystal phases, including unreacted oxide precursors, metastable tetragonal ( $\left.\mathrm{T}^{\prime}\right)$ structures ${ }^{19}$, orthorrombic $(\mathrm{O})$ and monoclinic phases (M), corresponding to $\mathrm{Nd}_{3} \mathrm{TaO}_{7}$ and $\mathrm{NdTaO}_{4}$, respectively ${ }^{14,20}$. The ceramics processed at $1200{ }^{\circ} \mathrm{C}$ and $1300{ }^{\circ} \mathrm{C}$ exhibited very similar result with a high degree of crystallinity, and they could be indexed with ICDD (International Committee for Diffraction Data) card number \#33-0941. Figure 1b shows XRD details in the range of 25$31^{\circ} 2 \theta$, where each peak could be identified in agreement with the ICDD cards and previously published works ${ }^{14,19,20}$.

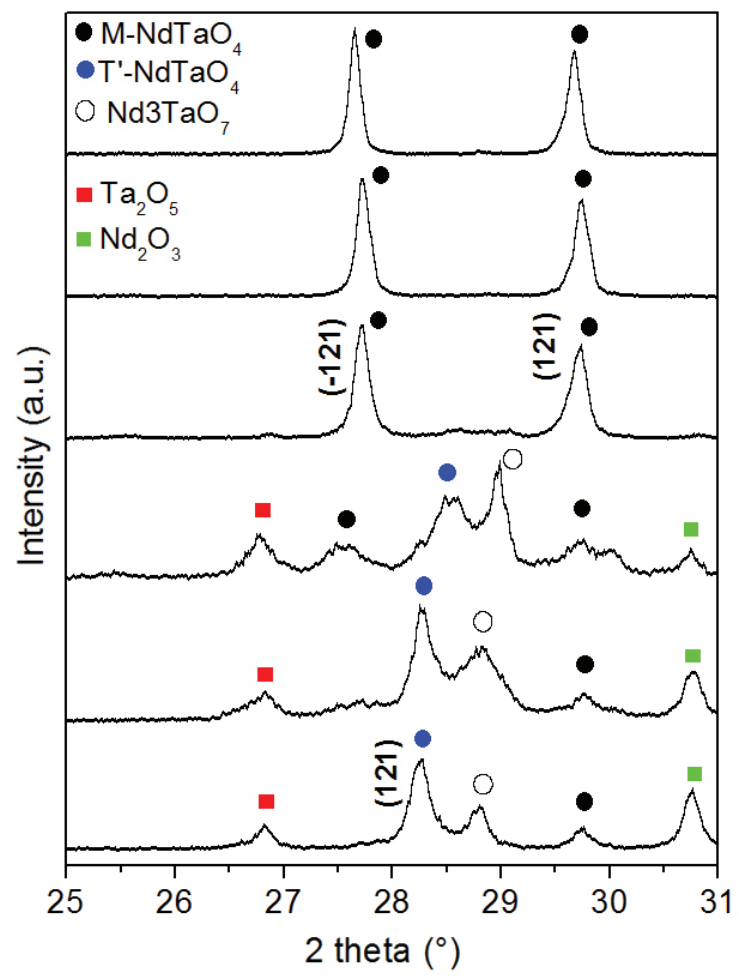

(b)

Figure 1. (a) Thermal evolution for the $\mathrm{NdTaO}_{4}$ compound in the temperature range $800-1300{ }^{\circ} \mathrm{C}$, for fixed times of $6 \mathrm{~h}$, studied by XRD. (b) XRD details in the range $25-31^{\circ} 2 \theta$. 
We can observe that the diffraction patterns of samples heated at $1200{ }^{\circ} \mathrm{C}$ and $1300{ }^{\circ} \mathrm{C}$ exhibit a single monoclinic phase belonging to the space group I2/a $\left(\mathrm{C}_{2 h}^{6}, \# 15\right)$ with four units per unit cell. For the sample produced at $1300{ }^{\circ} \mathrm{C}$, the following lattice parameters could be calculated: $\mathrm{a}=5.516$ $\AA ; \mathrm{b}=11.246 \AA ; \mathrm{c}=5.116 \AA$ and $\beta=95.7^{\circ}$.

According to the literature, $\mathrm{NdTaO}_{4}$ materials present many polymorphs ${ }^{10,19}$. At room temperature, this compound crystallizes in the M- and M'-fergusonite structures ${ }^{10}$. At low temperatures, the ceramic crystallizes in a metastable tetragonal ( $\mathrm{T}^{\prime}$ ) structure ${ }^{19}$, while under high pressures the monoclinic $\mathrm{LaTaO}_{4}$-type structure can be obtained ${ }^{10}$. Although many attempts have been made by several calcining conditions, the polymorphs could not be obtained for the $\mathrm{NdTaO}_{4}$ in this work. The unique single phase observed was the monoclinic M-fergusonite. Figure 2 plots the relative amount of monoclinic phase in the region of coexisting phases obtained from the XRD patterns. The ratio of the monoclinic (M) phase to the metastable tetragonal ( $\mathrm{T}^{\prime}$ ) phase is determined from the integral intensities of the monoclinic XRD peaks (-121) and (121) and the tetragonal XRD peak (121) using the following relationship ${ }^{21,22}$ :

$M(\%)=\frac{I_{M}(-121)+I_{M}(121)}{I_{M}(-121)+I_{M}(121)+I_{T}(121)} \times 100$

where $M(\%)$ is the proportion of the monoclinic phase; $I_{M}$ is the intensity of the peak from the monoclinic phase and $I_{T}$ is the intensity of the peak from the metastable tetragonal phase. We can observe that the proportion of the monoclinic phase increases with the increasing of the calcining temperature. The variation of the relative amount of each phase as a function of calcining temperature can be explained by the homogenization of the composition and the enhancement of diffusion ${ }^{21}$.

The inset in Figure 2 presents the Raman spectra of samples processed at 800 and $1300^{\circ} \mathrm{C}$. In the first spectrum, we can observe broad Raman modes corresponding to a mixture of crystal phases. The spectrum for the calcined sample at $1300{ }^{\circ} \mathrm{C}$ shows the presence of all Raman-active modes in agreement with group-theory calculations, as discussed below. In the arrangement $\mathrm{I} 2 / \mathrm{a}, \mathrm{Nd}$ and $\mathrm{Ta}$ ions occupy the Wyckoff position $4 e$, while two oxygen occupy the site $8 f$. Based in these occupation sites, the site-group method of Rousseau et al. ${ }^{23}$ was applied to obtain the following Raman-active modes:

$\Gamma_{\text {RAMAN }}=8 \mathrm{~A}_{\mathrm{g}}+10 \mathrm{~B}_{\mathrm{g}}$

The results depicted in Figure 2 show that all these bands could be visualized in the ceramic processed at $1300{ }^{\circ} \mathrm{C}$, which indicates that the single monoclinic phase was obtained as also detected by XRD. All phonon wavenumbers $\left(\mathrm{cm}^{-1}\right)$ and assignments for the $\mathrm{NdTaO}_{4}$ monoclinic sample could be obtained as follows: $109.6\left(\mathrm{~A}_{\mathrm{g}}\right), 131.4\left(\mathrm{~A}_{\mathrm{g}}\right)$, $172.5\left(\mathrm{~B}_{\mathrm{g}}\right), 187.0\left(\mathrm{~A}_{\mathrm{g}}\right), 202.7\left(\mathrm{~B}_{\mathrm{g}}\right), 214.9\left(\mathrm{~B}_{\mathrm{g}}\right), 229.4\left(\mathrm{~A}_{\mathrm{g}}\right)$, $308.0\left(\mathrm{~B}_{\mathrm{g}}^{\mathrm{g}}\right), 322.5\left(\mathrm{~A}_{\mathrm{g}}^{\mathrm{g}}\right), 344.3\left(\mathrm{~B}_{\mathrm{g}}\right), 375.7\left(\mathrm{~B}_{\mathrm{g}}^{\mathrm{g}}\right), 412.0\left(\mathrm{~B}_{\mathrm{g}}^{\mathrm{g}}\right)$, $433.8\left(\mathrm{~B}_{\mathrm{g}}\right), 467.7\left(\mathrm{~A}_{\mathrm{g}}\right), 634.6\left(\mathrm{~B}_{\mathrm{g}}\right), 641.9\left(\mathrm{~A}_{\mathrm{g}}\right), 675.8\left(\mathrm{~B}_{\mathrm{g}}\right)$, $813.7\left(\mathrm{~A}_{\mathrm{g}}\right)$.

After we determine the ideal temperature to produce single phase $\mathrm{NdTaO}_{4}$, we applied the same conditions to produce the $\mathrm{LaTaO}_{4}$, i.e. $1300{ }^{\circ} \mathrm{C}$ and $6 \mathrm{~h}$. However, to obtain the lanthanum single-phase was necessary to use longer processing times. For $\mathrm{LaTaO}_{4}$ ceramics, longer processing times were tested and the evolution of the crystalline phase was monitored till its stabilization. Figure 3 presents typical XRD patterns for samples processed at $1300^{\circ} \mathrm{C}$, for 6 and $14 \mathrm{~h}$. The materials crystallize in the monoclinic structure with space group $\mathrm{P} 2_{1} / \mathrm{c}\left(\mathrm{C}_{2 h}^{5}, \# 14\right)$

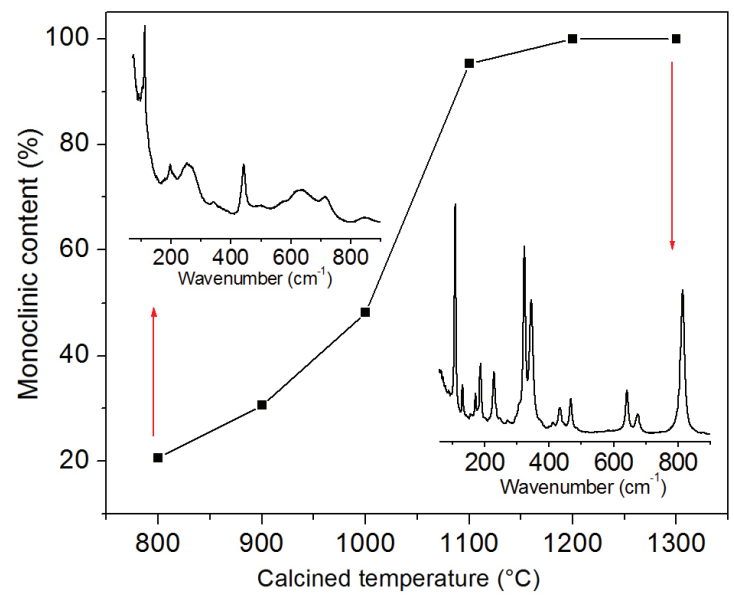

Figure 2. Monoclinic content of $\mathrm{M}-\mathrm{NdTaO}_{4}$ powders calcined at different temperatures, for $6 \mathrm{~h}$. In the inset are the Raman spectra of samples processed at $800{ }^{\circ} \mathrm{C}$ and $1300{ }^{\circ} \mathrm{C}$.

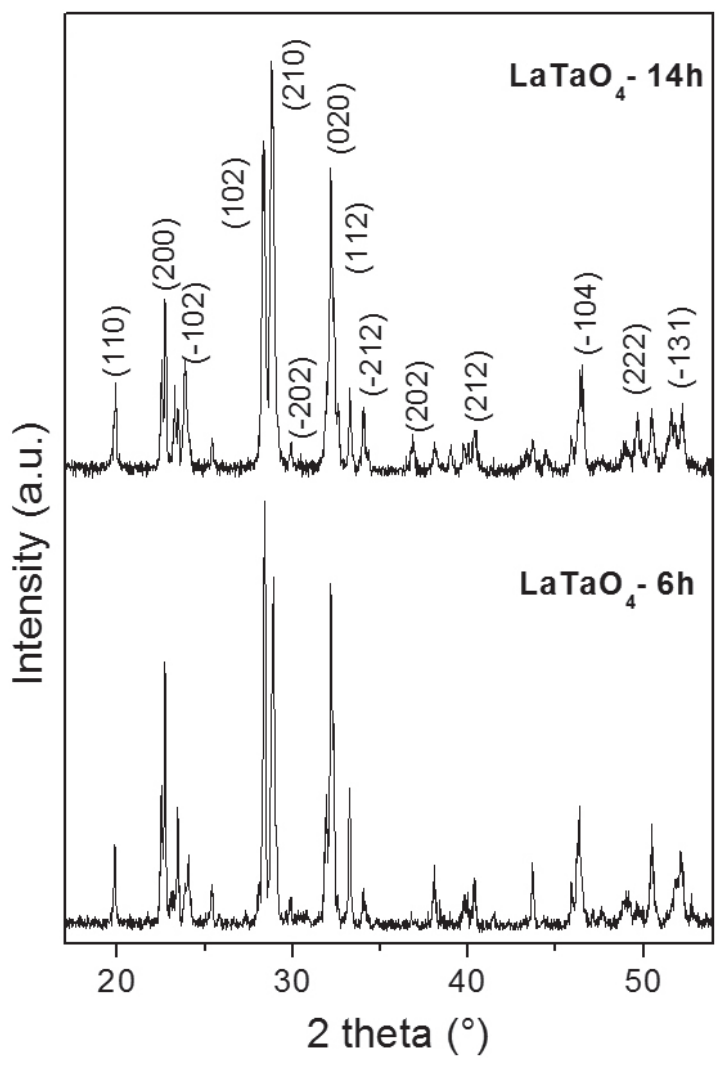

Figure 3. XRD results for the $\mathrm{LaTaO}_{4}$ ceramics calcined at $1300^{\circ} \mathrm{C}$, for 6 and $14 \mathrm{~h}$. Note the similarity between the patterns. 
Table 1. Factor-group analysis for $\mathrm{LaTaO}_{4}$ and lattice parameters calculated for samples produced in different time conditions.

\begin{tabular}{|c|c|c|c|c|}
\hline \multicolumn{5}{|c|}{$\mathrm{LaTaO}_{4}$ - space group $\mathrm{P}_{1} / \mathrm{c}(\# 14)$} \\
\hline Processing time & a (Å) & b $(\AA)$ & c $(\AA)$ & $\beta\left({ }^{\circ}\right)$ \\
\hline $6 \mathrm{~h}$ & 7.7199 & 5.5606 & 8.1257 & 103.58 \\
\hline $14 \mathrm{~h}$ & 7.7008 & 5.5606 & 8.1220 & 103.66 \\
\hline Atom & Wyckoff sites & & \multirow{7}{*}{\multicolumn{2}{|c|}{$\Gamma \operatorname{Raman}=8 \mathrm{Ag}+10 \mathrm{Bg}$}} \\
\hline $\mathrm{La}$ & $4 e$ & & & \\
\hline $\mathrm{Ta}$ & $4 e$ & & & \\
\hline $\mathrm{O}(1)$ & $4 e$ & & & \\
\hline $\mathrm{O}(2)$ & $4 e$ & & & \\
\hline $\mathrm{O}(3)$ & $4 e$ & & & \\
\hline $\mathrm{O}(4)$ & $4 e$ & & & \\
\hline
\end{tabular}

and $\mathrm{Z}=4$. The main crystallographic planes indexed by the ICDD card \#72-1808 are identified in Figure 3. The lattice parameters for each sample were calculated and are showed in Table 1. We can observe a slight change in the parameters from 6 to $14 \mathrm{~h}$, although the parameter $b$ remains the same. The XRD patterns for these two $\mathrm{LaTaO}_{4}$ samples are very similar with small differences observed at around $37^{\circ} 2 \theta$, as well as the inversion of the relative intensities of the planes (121) and (-121). However, the results from Raman scattering showed significant changes in the spectra for the samples produced for 6 and $14 \mathrm{~h}$. Figure 4 shows the Raman spectra for these two particular samples. The two spectra were superimposed to the better comparison. The black and red spectra correspond to samples calcined for $6 \mathrm{~h}$ and $14 \mathrm{~h}$, respectively. It can be observed that the red spectrum presents more defined modes than the black one. We believe that after $6 \mathrm{~h}$ of processing the ceramic presents short-range disorder, which could not be detected by XRD.

Raman bands appear broader for $\mathrm{LaTaO}_{4}$ samples produced for $6 \mathrm{~h}$ in comparison with the modes observed after $14 \mathrm{~h}$, which indicates that it is necessary longer processing times to attain a short-range order. For these samples, 36 Raman-active modes are predicted by grouptheory (see Table 1), in agreement with our experimental data depicted in Figure 4 (red spectrum). Comparing the results for $\mathrm{LaTaO}_{4}$ and $\mathrm{NdTaO}_{4}$ ceramics, we can assert that the processing time to produce a single-phase sample with high degree of crystallinity is related with the nature of the material, in other words, the processing time is strongly related with lanthanide size. For the $\mathrm{NdTaO}_{4}$ sample $\left(\mathrm{Nd}^{3+}=0.983 \AA\right)$, it is necessary $6 \mathrm{~h}$ of processing at $1300^{\circ} \mathrm{C}$, while for $\mathrm{LaTaO}_{4}\left(\mathrm{La}^{3+}=1.032 \AA\right)$ it is necessary $14 \mathrm{~h}$ at this temperature ${ }^{24}$.

Now we will discuss the influence of processing parameters on the arrangement acquired by orthotantalates. In this case, the polymorphic transitions in the $\mathrm{DyTaO}_{4}$ sample from M-fergusonite to M'-fergusonite structures may be observed and it was caused by changing only on temperature of synthesis. The $\mathrm{DyTaO}_{4}$ sample was firstly synthesized at $1300{ }^{\circ} \mathrm{C}$ for fixed times of $6 \mathrm{~h}$ (same conditions employed for $\mathrm{NdTaO}_{4}$ ). Under these conditions, $\mathrm{DyTaO}_{4}$ samples crystallized in $\mathrm{M}^{\prime}$-fergusonite structure with space group $\mathrm{P} 2 / \mathrm{a}\left(\mathrm{C}_{2 h}^{4}\right.$, \#13) with 2 units per unit cell. In spite that we have already achieved a crystalline

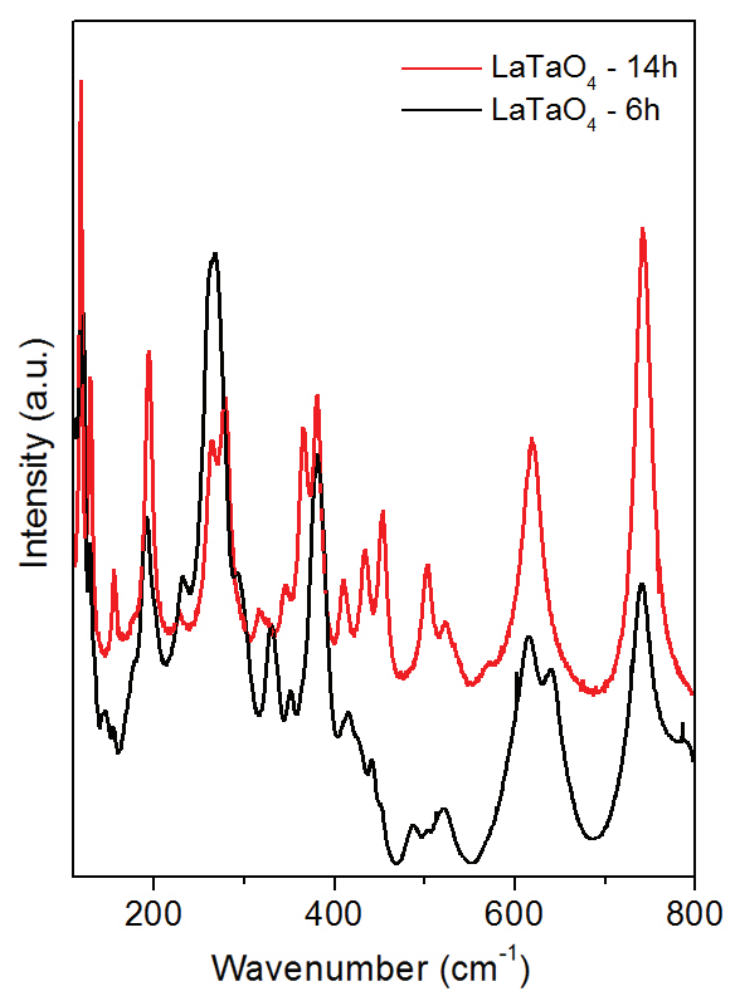

Figure 4. Raman spectra for $\mathrm{LaTaO}_{4}$ calcined at $1300{ }^{\circ} \mathrm{C}$, for $6 \mathrm{~h}$ (black line) and $14 \mathrm{~h}$ (red line). Note the difference in the full width at half-maxima of the depicted modes, indicating the higher level of ordering in the red spectrum, which could be related to the longer processing time.

phase, our study was beyond and additional experiments were conducted at higher temperatures in order to observe possible phase transitions. After calcining at $1500^{\circ} \mathrm{C}$, it was observed a new polymorphic form. The $\mathrm{DyTaO}_{4}$ sample exhibited the same structure of $\mathrm{NdTaO}_{4}$, i.e. M-fergusonite structure with space group I2/a (\#15).

Figure 5 presents the XRD results for these samples produced at low $\left(1300^{\circ} \mathrm{C}\right)$ and high $\left(1500^{\circ} \mathrm{C}\right)$ temperatures, for $6 \mathrm{~h}$. Single-phase, crystalline ceramics were obtained after synthesis without contaminants or secondary phases. In the inset of the Figure 5 we can observe the 


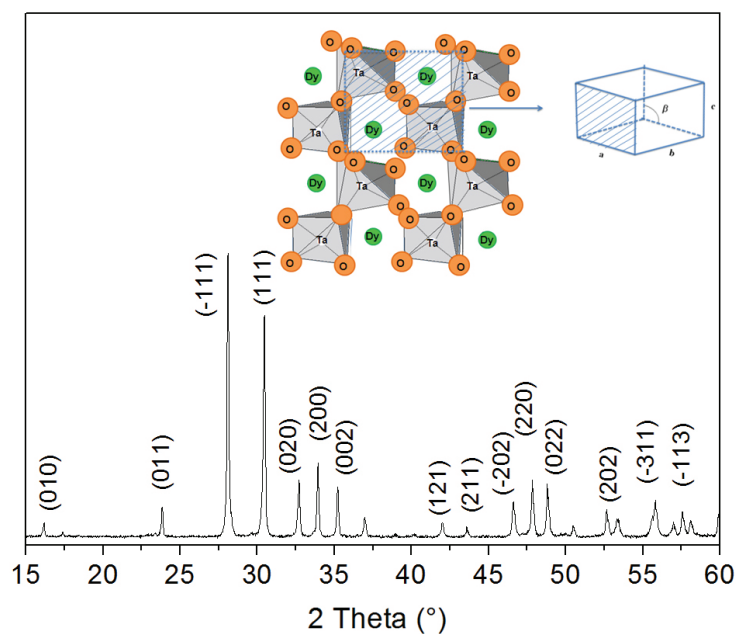

(a)

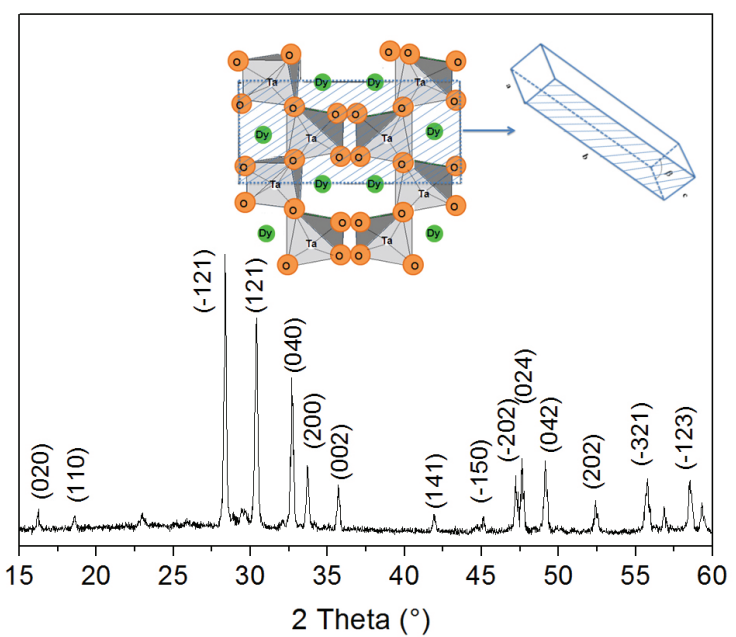

(b)

Figure 5. XRD patterns for the $\mathrm{DyTaO}_{4}$ polymorphs with the respective crystallographic planes indexed: (a) M'-fergusonite (P2/a); (b) M-fergusonite (I2/a). In the inset are the crystallographic projections and their respective Bravais lattice representations illustrating the peculiarities of each polymorphic.

Table 2. Comparative results between the lattice parameters and unit cell volume of $\mathrm{DyTaO}_{4}$ for the two polymorphs: $\mathrm{M}$ '-fergusonite and M-fergusonite.

\begin{tabular}{|c|c|c|c|c|c|c|c|c|c|}
\hline \multirow{2}{*}{$\begin{array}{l}\text { Polymorphic } \\
\text { form }\end{array}$} & \multirow[t]{2}{*}{$\mathbf{T}\left({ }^{\circ} \mathbf{C}\right)$} & \multicolumn{4}{|c|}{ Lattice parameters } & \multicolumn{3}{|c|}{ Ratios } & \multirow[t]{2}{*}{$\mathbf{V}\left(\AA^{3}\right)$} \\
\hline & & $\mathbf{a}(\AA)$ & $\mathbf{b}(\AA)$ & c $(\AA)$ & $\beta\left(^{\circ}\right)$ & $\mathbf{a} / \mathbf{b}$ & $\mathbf{b} / \mathbf{c}$ & $\mathbf{c} / \mathbf{a}$ & \\
\hline $\begin{array}{l}\mathrm{M}^{\prime}-\mathrm{DyTaO}_{4} \\
\mathrm{P} 2 / \mathrm{a}(\# 13)\end{array}$ & 1300 & 5.2891 & 5.4720 & 5.1009 & 92.73 & 0.9666 & 1.0728 & 0.9644 & 147.63 \\
\hline $\begin{array}{l}\text { M-DyTaO } \\
\text { I2/a }(\# 15)\end{array}$ & 1500 & 5.0646 & 10.9539 & 5.0312 & 92.77 & 0.4624 & 2.1772 & 0.9934 & 279.12 \\
\hline
\end{tabular}

crystallographic projections and their respective Bravais lattice representations, for a better view of the peculiarities of each polymorphic sample. The main difference between these two arrangements is in the coordination of Ta atom, being four for the M-fergusonite structure and six for M'fergusonite structure ${ }^{14}$. Thus, in the M-type structure the Ta atoms have a tetrahedral coordination, while they exist in a distorted octahedron in M'-type. Furthermore, the average $\mathrm{Ta}-\mathrm{O}$ distance is longer in the M-type structure, which results in a higher unit cell volume for this arrangement ${ }^{14}$. The lattice parameters calculated and unit cell volume are present in the Table 2, for a better comparison between the two polymorphs. We can observe that in the both arrangements the relation among the lattice parameters is the same: $b>a>c$. However, in the sample obtained at low temperature $(\mathrm{P} 2 / \mathrm{a})$ the parameter $b$ is almost the half than the calculated for the sample produced at high temperature (I2/a).

Figure 6 presents the results obtained from Raman scattering measurements at room temperature for the two polymorphs $\mathrm{DyTaO}_{4}$. In both samples we can observe all the 18 active modes predicted by group-theory. Table 3 shows phonon wavenumbers and assignments of each Raman-active mode. As already presented previously for the $\mathrm{NdTaO}_{4}$ sample, the group-theory for I2/a structure (Equation 2) is the same that for P2/a space group. Although the structures for both polymorphs exhibit an equal number

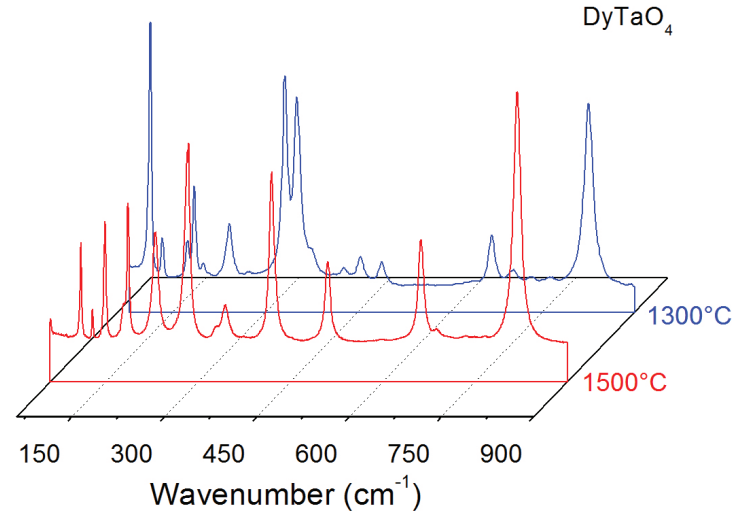

Figure 6. Raman spectra for the compounds $\mathrm{M}-\mathrm{DyTaO}_{4}$ calcined at $1500{ }^{\circ} \mathrm{C}$ (red) and $\mathrm{M}^{\prime}-\mathrm{DyTaO}_{4}$ produced at $1300{ }^{\circ} \mathrm{C}$ (blue). The spectral region is from 60 to $900 \mathrm{~cm}^{-1}$ and the spectra were normalized for a better comparison.

of Raman-active modes, they present different spectra. In the Figure 6 the blue spectrum corresponds to the M'Dy $\mathrm{TaO}_{4}$ ceramic, while the red spectrum corresponds to the $\mathrm{M}-\mathrm{DyTaO}$ compound. We can observe that the red spectrum is very similar with the obtained for $\mathrm{NdTaO}_{4}$ (see inset of the Figure 3 ) because both samples belong to the same space group (I2/a). If we compare the spectra of M- 
and $\mathrm{M}^{\prime}$ - $\mathrm{DyTaO}_{4}$, we can observe a change (decreasing and increasing) of relative intensity of the modes through the transition M-fergusonite to M'-fergusonite. This difference could be attributed to the new structural arrangement assumed by the sample when it changes from one structure to another. Furthermore, if we observe the assign of active Raman-modes of these fergusonite-type structures (see Table 2), we can assume that the crystalline arrangement regarding the M-type fergusonites seems to favor the $\mathrm{A}_{\mathrm{g}}$ modes, while the arrangement observed in M'-type structures seems to favor the $\mathrm{B}_{\mathrm{g}}$ modes.

Table 4 presents a summary of all samples produced in these work by different parameters and the respective results. Through the detailed study concerning the processing of these ceramics, we can determine the more simple way to

Table 3. Phonon wavenumbers $\left(\mathrm{cm}^{-1}\right)$ and assignments obtained from Raman experimental data for the $\mathrm{DyTaO}_{4}$ in the two arrangements $\mathrm{M}$ '-fergusonite and $\mathrm{M}$-fergusonite.

\begin{tabular}{cccc}
\hline Mode & Assignment & \multicolumn{2}{c}{ Wavenumber $\left(\mathbf{c m}^{-1}\right)$} \\
\cline { 3 - 4 } & & 109.7 & 113.8 \\
\hline 1 & $\mathrm{~A}_{\mathrm{g}}$ & 128.7 & 133.1 \\
2 & $\mathrm{~A}_{\mathrm{g}}$ & 148.9 & 174.2 \\
3 & $\mathrm{~B}_{\mathrm{g}}$ & 179.6 & 185.0 \\
4 & $\mathrm{~A}_{\mathrm{g}}$ & 186.5 & 199.5 \\
5 & $\mathrm{~B}_{\mathrm{g}}$ & 221.6 & 232.1 \\
6 & $\mathrm{~B}_{\mathrm{g}}$ & 231.2 & 241.8 \\
7 & $\mathrm{~A}_{\mathrm{g}}$ & 283.4 & 274.4 \\
8 & $\mathrm{~B}_{\mathrm{g}}$ & 329.4 & 332.3 \\
9 & $\mathrm{~A}_{\mathrm{g}}$ & 344.6 & 351.7 \\
10 & $\mathrm{~B}_{\mathrm{g}}$ & 373.9 & 374.6 \\
11 & $\mathrm{~B}_{\mathrm{g}}$ & 419.5 & 428.9 \\
12 & $\mathrm{~B}_{\mathrm{g}}$ & 444.4 & 455.5 \\
13 & $\mathrm{~B}_{\mathrm{g}}$ & 510.9 & 489.3 \\
14 & $\mathrm{~A}_{\mathrm{g}}$ & 597.6 & 623.3 \\
15 & $\mathrm{~B}_{\mathrm{g}}$ & 662.2 & 668.0 \\
16 & $\mathrm{~A}_{\mathrm{g}}$ & 689.6 & 703.0 \\
17 & $\mathrm{~B}_{\mathrm{g}}$ & 818.5 & 824.9 \\
18 & $\mathrm{~A}_{\mathrm{g}}$ & & \\
\hline
\end{tabular}

obtain pure, single-phase La, Nd and Dy orthotantalates. Furthermore, we were able to determine the ideal conditions to obtain the $\mathrm{DyTaO}_{4}$ in both $\mathrm{M}$ - and $\mathrm{M}$ '-fergusonite arrangements by solid-state chemistry. All these information are very important and we hope that describing the synthesis methodology and results reported here could help in the development of upcoming works related to orthotantalates. It is important to note that the processing conditions and their influence in the final crystal structures are only the first step to obtain samples with high performance in the respective application. Moreover, we can see that the temperature, time and lanthanide size are directly correlated with the crystalline arrangement for the orthotantalate materials.

\section{Conclusions}

Lanthanide orthotantalates $\mathrm{LnTaO}_{4}(\mathrm{Ln}=\mathrm{La}, \mathrm{Nd}$ and Dy) were synthesized by solid-state reaction. The processing conditions to obtain all of these ceramics were reported and discussed in detail in this work for the first time in the literature. Particularly, the effects of temperature, time and lanthanide size on the crystal structures were investigated. For the $\mathrm{NdTaO}_{4}$ compound, the temperature of $1200 / 1300$ ${ }^{\circ} \mathrm{C}$ and processing times of $6 \mathrm{~h}$ were employed to obtain single-phase ceramics with $\mathrm{M}$-fergusonite structure, space group I2/a $\left(\mathrm{C}_{2 h}^{6}, \# 15\right)$. At temperatures below $1100{ }^{\circ} \mathrm{C}$, a mixture of crystal phases were found: unreacted precursors, monoclinic $(\mathrm{M})$, orthorhombic $(\mathrm{O})$, and metastable tetragonal ( $\left.\mathrm{T}^{\prime}\right)$ structures. The $\mathrm{LaTaO}_{4}$ crystallizes in the $\mathrm{P} 2_{1} / \mathrm{c}\left(\mathrm{C}_{2 h}^{5}, \# 14\right)$ space group at $1300^{\circ} \mathrm{C}$, for $14 \mathrm{~h}$. It was also produced the two polymorphs for $\mathrm{DyTaO}_{4}$ compounds. The crystal phase M'-fergusonite (P2/a, $\mathrm{C}_{2 h}^{4}$, \#13) was obtained at $1300^{\circ} \mathrm{C}$, while the M-fergusonite (I2/a, $\mathrm{C}_{2 h}^{6}$, \#15) was produced at $1500{ }^{\circ} \mathrm{C}$. All crystal structures were determined by XRD and Raman scattering. Finally, we could establish a set of processing parameters (temperature, time and ionic radii) that could be related to the final crystal structure exhibited by the lanthanide orthotantalates.

\section{Acknowledgements}

The authors thank the financial support from CNPq, FINEP and FAPEMIG.

Table 4. List of all obtained samples in this work as a function of processing parameters: temperature, time and lanthanide ion.

\begin{tabular}{|c|c|c|c|c|}
\hline Sample & Temperature $\left({ }^{\circ} \mathbf{C}\right)$ & Time (h) & Resulting Sample & Space group \\
\hline \multirow{6}{*}{$\mathrm{NdTaO}_{4}$} & 800 & 6 & ${ }^{1}$ Mixture of phases & - \\
\hline & 900 & 6 & ${ }^{1}$ Mixture of phases & - \\
\hline & 1000 & 6 & ${ }^{1}$ Mixture of phases & - \\
\hline & 1100 & 6 & $\mathrm{M}-\mathrm{NdTaO}_{4}$ & $\mathrm{I} 2 / \mathrm{a}$ \\
\hline & 1200 & 6 & $\mathrm{M}-\mathrm{NdTaO}_{4}$ & $\mathrm{I} 2 / \mathrm{a}$ \\
\hline & 1300 & 6 & $\mathrm{M}-\mathrm{NdTaO}_{4}$ & $\mathrm{I} 2 / \mathrm{a}$ \\
\hline \multirow[t]{2}{*}{$\mathrm{LaTaO}_{4}$} & 1300 & 6 & ${ }^{2} \mathrm{LaTaO}_{4}$ & $\mathrm{P} 2 / \mathrm{c}$ \\
\hline & 1300 & 14 & ${ }^{3} \mathrm{LaTaO}_{4}$ & $\mathrm{P} 2 / \mathrm{c}$ \\
\hline \multirow[t]{2}{*}{$\mathrm{DyTaO}_{4}$} & 1300 & 6 & $\mathrm{M}^{\prime}-\mathrm{DyTaO}_{4}$ & $\mathrm{I} 2 / \mathrm{a}$ \\
\hline & 1500 & 6 & M-DyTaO 4 & $\mathrm{I} 2 / \mathrm{a}$ \\
\hline
\end{tabular}

1) Phases present $=\mathrm{M}-\mathrm{NdTaO}_{4}+\mathrm{T}^{\prime}-\mathrm{NdTaO}_{4}+\mathrm{Nd}_{3} \mathrm{TaO}_{7}+\mathrm{Nd}_{2} \mathrm{O}_{3}+\mathrm{Ta}_{2} \mathrm{O}_{5}$; 2) Sample with long-range ordering detected by XRD (not Raman); 3) Sample with long- and short-range ordering detected by XRD and Raman measurements, respectively. 


\section{References}

1. Nyman M, Rodriguez MA, Alam TM, Anderson TM and Ambrosini A. Aqueous synthesis and structural comparison of rare-earth niobates and tantalates: $\left(\mathrm{La}, \mathrm{K},{ }_{2} \mathrm{Nb}_{2} \mathrm{O}_{7-\mathrm{x}}(\mathrm{OH})_{2}\right.$ and $\mathrm{Ln}_{2} \mathrm{Ta}_{2} \mathrm{O}_{7}(\mathrm{OH})_{2}$ ( = vacancy; $\left.\mathrm{Ln}=\mathrm{La}-\mathrm{Sm}\right)$. Chemistry of Materials. 2009; 21(11):2201-2208. http://dx.doi.org/10.1021/ cm9001509

2. Abe R, Higashi M, Zou Z, Sayama K, Abe $Y$ and Arakawa H. Photocatalytic water splitting into $\mathrm{H}_{2}$ and $\mathrm{O}_{2}$ over $\mathrm{R}_{3} \mathrm{TaO}_{7}$ and $\mathrm{R}_{3} \mathrm{NbO}_{7}(\mathrm{R}=\mathrm{Y}, \mathrm{Yb}, \mathrm{Gd}, \mathrm{La})$ : Effect of crystal structure on photocatalytic activity. Journal of Physical Chemistry B. 2004; 108(3):811-814. http://dx.doi.org/10.1021/jp036300v

3. Machida M, Yabunaka J and Kijima T. Synthesis and photocatalytic property of layered perovskite tantalates, $\mathrm{RbLnTa}_{2} \mathrm{O}_{7}(\mathrm{Ln}=\mathrm{La}, \mathrm{Pr}, \mathrm{Nd}$ and $\mathrm{Sm})$. Chemistry of Materials. 2000; 12(3):812-817. http://dx.doi.org/10.1021/ cm990577j

4. Zhang H, Wang Y and Xie L. Luminescent properties of $\mathrm{Tb}^{3+}$ activated $\mathrm{GdTaO}_{4}$ with $\mathrm{M}$ and $\mathrm{M}$ ' type structure under UV-VUV excitation. Journal of Luminescence. 2010; 130(11):20892092. http://dx.doi.org/10.1016/j.jlumin.2010.05.032

5. Li B, Gu Z, Lin J and Su M-Z. Photoluminescence of $\mathrm{Eu}^{3+}$ -activated $\mathrm{GdTaO}_{4}$ with $\mathrm{M}$ type and $\mathrm{M}^{*}$ type structures. Journal of Materials Science. 2000; 35(5):1139-1143. http://dx.doi. org/10.1023/A:1004767916006

6. Liu W, Zhang Q, Zhou W, Gu C and Yin S. Growth and luminescence of M-type $\mathrm{GdTaO}_{4}$ and $\mathrm{Tb}: \mathrm{GdTaO}_{4}$ scintillation single crystals. IEEE Tansactions on Nuclear Science. 2010; 57(3):1287-1290. http://dx.doi.org/10.1109/ TNS.2009.2037320

7. Arellano I, Nazarov M, Byeon CC, Popovici E-J, Kim H, Kang $\mathrm{HC}$ et al. Luminescenscence and structural properties of $\mathrm{Y}(\mathrm{Ta}, \mathrm{Nb})_{4}: \mathrm{Eu}^{3+}, \mathrm{Tb}^{3+}$ phosphors. Materials Chemistry and Physics. 2010; 119(1-2):48-51. http://dx.doi.org/10.1016/j. matchemphys.2009.07.038

8. Forbes TZ, Nyman M, Rodriguez MA and Navrotsky A. The energetics of lanthanum tantalate materials. Journal of Solid State Chemistry. 2010; 183(11):2516-2521. http://dx.doi. org/10.1016/j.jssc.2010.08.024

9. Haugsrud R and Norby T. Proton conduction in rare-earth orthoniobates and ortho-tantalates. Nature Materials. 2006; 5(3):193196. http://dx.doi.org/10.1038/nmat1591

10. Titov YA, Sych AM, Sokolov AN, Kapshuk AA, Markiv VY and Belyavina NM. Crystal structure of the highpressure modification of $\mathrm{NdTaO}_{4}$. Journal of Alloys and Compounds. 2000; 311(2):252-255. http://dx.doi.org/10.1016/ S0925-8388(00)01043-4

11. Santoro A, Marezio M, Roth RS and Minor D. Neutron powder diffraction study of the structures of $\mathrm{CeTaO}_{4}, \mathrm{CeNbO}_{4}$ and $\mathrm{NdTaO}_{4}$. Journal of Solid State Chemistry. 1980; 35(2):167175. http://dx.doi.org/10.1016/0022-4596(80)90489-2

12. Cava RJ and Roth RS. The structure of $\mathrm{LaTaO}_{4}$ at $300^{\circ} \mathrm{C}$ by neutron powder profile analysis. Journal of Solid
State Chemistry. 1981; 36(2):139-147. http://dx.doi. org/10.1016/0022-4596(81)90149-3

13. Hartenbach I, Lissner F, Nikelski T, Meier SF, Munz- HM and Schleid T. About Lanthanide Oxotantalates with formula $\mathrm{MTaO}_{4}(\mathrm{M}=\mathrm{La}-\mathrm{Nd}, \mathrm{Sm}-\mathrm{Lu})$. Zeitschrift fur anorganische und allgemeine Chemie. 2005; 631(12):2377-2382. http://dx.doi. org/10.1002/zaac.200500278

14. Siqueira KPF, Carvalho GB and Dias A. Influence of processing conditions and chemical environmental on the crystal structures and phonon modes of lanthanide orthotantalates. Dalton Transactions. 2011; 40(37):9454-9460. http://dx.doi. org/10.1039/c1dt10783f

15. Markiv VY, Belyavina NM, Markiv MV, Titov YA, Sych AM, Sokolov AN et al. Peculiarities of polymorphic transformations in $\mathrm{YbTaO}_{4}$ and crystal structures of its modifications. Journal of Alloys and Compounds. 2002; 346(1-2):263-268. http://dx.doi. org/10.1016/S0925-8388(02)00504-2

16. Molchanov VV, Zuev MG, Plyasova LM and Bogdanov SV. Mechanochemical synthesis of yttrium and lanthanum tantalates. Inorganic Materials. 2004; 40(1):73-79. http:// dx.doi.org/10.1023/B:INMA.0000012182.99092.6b

17. Hristea A, Popovici E-J, Muresan L, Stefan M, Grecu R, Johansson A et al. Morpho-structural and luminescent investigations of niobium activated yttrium tantalate powders. Journal of Alloys and Compounds. 2009; 471(1-2):524-529. http://dx.doi.org/10.1016/j.jallcom.2008.04.009

18. Hayes W and Loudon R. Scattering of Light by Crystals. New York: Wiley; 1978.

19. Mather SA and Davies PK. Nonequilibrium phase formation in oxides prepared at low temperature: Fergusonite-related phases. Journal of the American Ceramic Society. 1995; 78(10):27372745. http://dx.doi.org/10.1111/j.1151-2916.1995.tb08049.x

20. Wakeshima M, Nishimine $H$ and Hinatsu Y. Crystal structures and magnetic properties of rare earth tantalates $\mathrm{RE}_{3} \mathrm{TaO}_{7}(\mathrm{RE}=$ rare earths $)$. Journal of Physics-Condensed Matter. 2004; 16(23):4103-4120.

21. Hsiao YJ, Fang TH, Chang YS, Chang YH, Liu CH, Ji LW et al. Structure and luminescent properties of $\mathrm{LaNbO}_{4}$ synthesized by sol-gel process. Journal of Luminescence. 2007; 126(2):866870. http://dx.doi.org/10.1088/0953-8984/16/23/025

22. Kuo CW, Lee YH, Fung KZ and Wang MC. Effect of $\mathrm{Y}_{2} \mathrm{O}_{3}$ addition on the phase transition and growth of YSZ nanocrystallites prepared by sol-gel process. Journal of Non-Crystalline Solids. 2005; 351(4):304-311. http://dx.doi. org/10.1016/j.jnoncrysol.2004.11.002

23. Rousseau DL, Bauman RP and Porto SPS. Normal mode determination in crystals. Journal of Raman Spectroscopy. 1981; 10(1):253-290. http://dx.doi.org/10.1002/ jrs. 1250100152

24. Shannon RD. Revised effective ionic-radii and systematic studies of interatomic distantances in halide and chalcogenides. Acta Crystallographica Section A. 1976; 32(1):751-767. http:// dx.doi.org/10.1107/S0567739476001551 